\title{
Evaluation of the application of an edible coating and different frying temperatures on acrylamide and fat content in potato chips
}

\section{Sara Trujillo-Agudelo', Ana Osorio', Faver Gómez', Jose Contreras-Calderón', Marta Mesías-Garcia ${ }^{2}$, Cristina Delgado-Andrade², Francisco Morales², Oscar Vega-Castro 1,3}

'BIOALI Research Group, Food Department, Faculty of Pharmaceutical and Food Sciences, University of Antioquia, Street 67 No. 53-108. Medellín, Colombia

${ }^{2}$ Instituto de Ciencia y Tecnología de Alimentos y Nutrición (ICTAN-CSIC), Madrid-, Spain

${ }^{3}$ American University Corporation, Career. 42 No. 52 - 06 (Av. La Playa), Medellín, Colombia

\begin{abstract}
The consumption of fried foods and specifically potatoes is associated with the development of cardiovascular and cancer diseases in the population due to these foods contain a high fat level and some toxic compounds such as acrylamide. The aim of the present work was to evaluate the effect of the application of an edible coating developed from whey proteins and rosemary extracts on the reduction of acrylamide and fat in potato chips. The methodology included factorial experimental design, taking as independent variables: percentage of whey protein (5-11\%), percentage of rosemary extract $(0-2 \%)$, and frying temperature $(170-190 \mathrm{C})$. The fat content was determined according to AOAC and acrylamide by LC-ESI-MS-MS. In addition, textural analyses were performed on potato chips. The content of acrylamide oscillated between 130 and $650 \mu \mathrm{g} / \mathrm{kg}$. The acrylamide content was significantly affected by the frying temperature $(p<0.05)$. The fat content ranged between 8 and $31 \%$. The firmness values ranged between 0.5 and $5.7 \mathrm{~N}$. It can be concluded that the edible coating reduces the content of acrylamide and fat during frying, in addition to improving the firmness of the potato. Therefore, the designed coating could be an alternative to the public health problem generated by the consumption of fried foods.
\end{abstract}

\section{Practical application}

The present investigation shows how the use of coatings from whey proteins with the addition of extracts of natural antioxidants from rosemary can reduce the formation of neo-formed contaminants (acrylamide) and adsorption of fat, which represents a great processing alternative for the industry that allows them to comply with the regulations, recommendations, and existing trends regarding to the consumption of healthier products. In addition, the use of the coating does not affect the sensory quality of the potatoes. This also represents an attractive alternative for consumers who demand increasingly safe and healthy and tasty products, favoring the decrease in the prevalence of degenerative diseases in world population.

\section{INTRODUCTION}

French fries are obtained by a frying process, which involves a total cooking of the food in a fatty medium (oil), at a temperature oscillating between 160 and 200 C. During the frying process, several chemical and physical reactions take place. These reactions modify the organoleptic characteristics of the food (Nieto, 2014), giving the product a certain texture and sensorial aspect and being responsible for the potato snack is in the highest category consumption worldwide. Specifically in Colombia, fried potatoes are mostly consumed as potato chips (snacks) and 24.5-44.4\% of the population between 5 and 64 years old consume them weekly (Ministerio de la Protección Social, 20II).

Fried foods are characterized by having a crunchy texture and a pleasant taste, producing satiety and being affordable, and easily acquired products (Gomez, Martinez, \& Cardona, 2014). However, FAO and World 
Health Organization (WHO) indicate that a high consumption of fried foods involves a risk factor for health, because their intake is associated with diseases such as diabetes, heart disease, stroke, and cancer (OMS, 2018). This fact is mainly due to the high energy density and the content of toxic compounds such as trans fatty acids (Suaterna, 2009), cyclic fatty acids, polar compounds (Suaterna, 2009), and acrolein, which can generate a delay in growth in children and hepatotoxicity (Bejarano \& Suarez, 20I5). Another of the toxic compounds formed during the frying process is acrylamide, classified as probably carcinogenic to humans (group 2A) by the International Agency for Research on Cancer (IARC, 1994). The dietary exposure to acrylamide is associated to the development of some types of cancer, and for that reason, the presence of this compound in foods is a matter of public health (EFSA, 2015). Acrylamide is a highly reactive molecule that is generated in foods at a temperature above $120 \mathrm{C}$ by the reaction between reducing sugars and amino acids, especially asparagine, which are naturally present in food. Acrylamide is mainly found in French fries, potato chips, bread and other bakery products, and coffee and coffee substitutes (EFSA, 20I5).

Due to the health concern associated with the fat content and the presence of acrylamide, it is important to look for alternatives that lead to healthier and more safety fried foods. This will help to reduce the risks associated with cardiovascular diseases and the impact of contaminants on health, but maintaining their sensorial and textural characteristics. With this objective, the industry has used different pretreatments in foods such as drying, blanching, osmotic dehydration, and high hydrostatic pressure (HHP) among others (González, Bermúdez, \& Morales, 2017). Currently, one of the most outstanding alternatives are the edible coatings (EC), which are defined as a continuous and thin matrix that is structured around the food generally by immersing it in a coating forming solution (Fernández Valdés et al., 2015). The main function of the EC is to protect the product from mechanical, physical, chemical damages, and microbiological activities that deteriorate it (Falguera, Quintero, Jiménez, Muñoz, \& Ibarz, 20I I).

Several authors have reported the use of EC to reduce the presence of toxic or fatty compounds in different dietary matrices. De Grandi Castro Freitas et al. (2009) showed the reduction of fat absorption during the frying process of a frozen cassava product by means of coatings formulated with pectin, whey protein, and soy protein isolate. In a similar way, Albert and Mittal (2002) described the application of II hydrocolloids for the design of different EC to reduce the fat content in a cereal such as biscuit and cookies. Sothornvit (201I) obtained similar results in fried banana chips, who achieved a reduction in oil content in banana chips between 17-25\%, using edible coatings made with guar gum or xanthan gum. However, Suyatma, Ulfah, Prangdimurti, and Ishikawa (2014) found that the use of hydrocolloids combined with the blanching of the banana, affected the reduction of the percentage of acrylamide in bananas chips. Regarding potato chips, Mallikarjunan, Chinnan, Balasubramaniam, and Phillips (1997), Zeng et al. (2010), Kim, Lim, Bae, Lee, and Lee (20II), Al-Asmar, Naviglio, Giosafatto, and Mariniello (20I8) found that the coatings helped to reduce oil absorption. Zeng et al. (2010) compared the effects of eight hydrocolloids concluding that pectin, alginic acid, and xanthan gum significantly reduced the acrylamide formation in potato chips. Similar results have been presented by Kurek, Scetar, and Galic (2017) and Mousa (2018) who found reductions between 33 and $45 \%$ for potato chips, using calcium caseinate and calcium pectinate, and gum Arabic as a coating, respectively. Another alternative for the reduction of acrylamide and fat absorption is the use of antioxidant extracts or polyphenols (Dueik \& Bouchon, 2016; Liu et al., 2015), which are natural compounds found in fruits (Silva \& Sirasa, 20I8), vegetables (Andarwulan et al., 20I2), herbs and spices (Embuscado, 20I5). In this sense, acrylamide formation has been reported to be reduced in French fries by the addition of polyphenolic extracts of grapes (Kalita, Holm, \& Jayanty, 2013; Xu et al., 2015) and rosemary extracts (Urbancic, Kolar, Dimitrijevic, Demšar, \& Vidrih, 2014). 
Currently, there are no reports in the literature on the combined use of EC of whey with rosemary antioxidant extract for the reduction of acrylamide and fat in potato chips, and therefore, this study is a first contribution to the development of this type of applications. The objective of this research was to develop an edible coating made from concentrated whey protein added with rosemary extract, and to study the effect on the reduction of acrylamide and fat content in potato chips. The effect on the texture and sensory quality of the product was also evaluated using commercial and street vending samples as reference.

\section{MATERIALS AND METHODS}

\section{I. Samples and Chemicals}

Raw potatoes used in this study were Diacol Capiro variety (same batch and brand), which were acquired in a local market. Commercial potato chips (same batch and brand) were also purchased in local market, whereas street vending samples were acquired in a potato stand close to the University. Chemicals included glycerol (PanreacQuímica, Spain), ascorbic acid (Hach), gelatin (Quala S.A., Colombia), and palm oil (C.I. Inversiones Americano S.A., Colombia). The concentrated whey protein powder (CWP 80\%) and the rosemary fatty extract (Rosemarinus officinalis L.) were obtained from Tecnas SA (Medellín/Colombia).

\subsection{Sample treatment}

Potatoes were washed with distilled water before peeling and cut into slices with a thickness of $\mathrm{I} \pm 0.2 \mathrm{~mm}$, using a manual cutting machine (Home Collection, Colombia). Subsequently, they were immersed in a solution of $0.05 \%$ ascorbic acid, with a potato/acid solution ratio of $2: 10$, for 15 min to avoid enzymatic browning. Once the contact time was over, the excess product solution was removed with the help of a disposable towel (Yu, Li, Ding, Hang, \& Fan, 2016).

\subsection{Formulation and preparation of the coating}

For the formulation and subsequent preparation of the coatings, the methodology proposed by De Grandi Castro Freitas et al. (2009) was followed, with some modifications. Initially, the concentrated whey protein $(5,8$, or $1 \mathrm{I} \mathrm{g})$ was dissolved in $100 \mathrm{~mL}$ of distilled water, and $9 \mathrm{~g}$ of glycerol was added as a plasticizer. After that, the solution was heated in a water bath (Lauda, Germany) at $90 \pm 2 \mathrm{C}$ for $30 \mathrm{~min}$. In parallel, $2 \mathrm{~g}$ of gelatin were dissolved in $40 \mathrm{~mL}$ of distilled water. This solution was heated in a water bath for $8 \mathrm{~min}$ at $90 \pm$ 2 C. Once the two solutions were prepared, they were mixed and homogenized in an Ultra Turrax disperser (Microdistech, MDT 1000) at a speed of 14,000 rpm for $60 \mathrm{~s}$. Once the two solutions were prepared, the rosemary oily extract $(7 \mathrm{~g})$ was added, and then, the mixture was homogenized. Once the coatings were prepared, they were stored in glass jars at $4 \pm I \quad C$ until use.

\subsection{Application of the coating}

The edible coating was applied to the potatoes according to the methodology proposed by De Grandi Castro Freitas et al. (2009). Briefly, each slice of potato was immersed in the coating for 15 s. Subsequently, the potatoes were dried in an oven (Binder, Model ED II5, Germany) with forced circulation for 35 min at $50 \pm 2^{\circ} \mathrm{C}$.

\subsection{Frying process}

The frying process was carried out following the methodology of Rimac-Brn ci c, Lelas, Rade, and Šimundi c (2004), with some modifications. An electric fryer (Hamilton Beach, Model 3502I) with a capacity of $2 \mathrm{~L}$ was used. A calibrated thermocouple was used to monitor the temperature of the frying oil. The ratio potato/oil palm was $1: 21$ in all frying treatments. Samples were fried for $120 \mathrm{~s}$ at temperatures ranging between $17 \mathrm{I}$ and $19^{\circ} \mathrm{C}$, according to the experimental design shown in Table $\mathrm{I}$. 


\subsection{Characterization of coated potato chips}

\subsection{Physical-chemical characterization}

For the characterization of the potato chips with coating, and commercial sample and street vending potato, the moisture and fat content was determined according to the AOAC (2005).

\subsubsection{Measurement of firmness}

The firmness analysis included coated chips, as well as commercial potatoes and potatoes distributed in street vending. The firmness of the potato chips was determined using a texture analyzer (TAXT plus, Stable Microsystems), as described by Yang, Achaerandio, and Pujolà (2016). The operating conditions used for the measurement were: pretest speed of $1 \mathrm{~mm} / \mathrm{s}$, test speed of $1 \mathrm{~mm} / \mathrm{s}$, posttest speed of $1 \mathrm{~mm} / \mathrm{s}$, distance of advance of $8 \mathrm{~mm}$, and force of shot of $0.98 \mathrm{I} \mathrm{N}$. A SMS ball probe P/0.25s was also used.

\subsubsection{Determination of acrylamide}

Acrylamide was determined as described by Mesías and Morales (2015). Grounded sample $(0.500 \mathrm{~g})$ was weighed and mixed with $9.4 \mathrm{~mL}$ of water in polypropylene centrifugal tubes. Two milliliters of hexane were added in the tubes to remove the fat content of the potato chips. Mixture was spiked with $100 \mu \mathrm{L}$ of a 5 $\mu \mathrm{g} / \mathrm{mL}\left[{ }^{13} \mathrm{C}_{3}\right]$-acrylamide methanolic solution as internal standard and later homogenized (Ultra Turrax, IKA, Mod-TIO basic, Germany) for 10 min. Afterwards, sample was treated with $250 \mu \mathrm{L}$ of each Carrez I (I5 g potassium ferrocyanide/100 mL water) and Carrez II (30 g zinc acetate/100 mL water) solutions and centrifuged $(9,000 \mathrm{~g}$ for $10 \mathrm{~min})$ at $4 \mathrm{C}$. Hexane was removed, and samples were cleaned up by using of Oasis-HLB cartridges. Solution was filtered through a $0.45-\mu \mathrm{m}$ filter into an amberlite LC-MS vial. Sample extracts and calibration standards were analyzed by LC-ESI-MS-MS, as described by Mesías and Morales (2015). The accuracy of this method for potato crisps has been recently demonstrated in three proficiency tests launched by the Food Analysis Performance Assessment Scheme (FAPAS) program, yielding a z-score of 0.2 (Test 3065, May-June 2016), -0.2 (Test 307I, Feb-March 20I7) and -0.3 (Test 3080, Feb-March 2018). Precision (reproducibility) was lower than 10\%, and recovery between 84 and 109\%. The limit of the quantitation was set at $20 \mu \mathrm{g} / \mathrm{kg}$. Analyses were performed in duplicate, and results were expressed as $\mu \mathrm{g} / \mathrm{kg}$ of product. The determination of the acrylamide content was made to the coated potato chips, commercial potatoes and potatoes distributed in street vending.

\subsubsection{Determination of antioxidant capacity and total phenolic compounds}

\section{Sample preparation}

The extraction of antioxidant compounds from potato chips and fresh potato was carried out following the methodology described by Contreras-Calderón, Guerra-Hernández, and García-Villanova (2009). Sample (I g) was subjected to the extraction, and extract was stored at $-18^{\circ} \mathrm{C}$ until use. Both extraction and measurements were made in triplicate.

\section{ABTS}

The analysis of ABTS was carried out according to Contreras-Calderón et al. (2009). One hundred microliters of extract diluted appropriately $(\mathrm{I} / \mathrm{I} 0)$ with distilled water was used for the determination, and the absorbance was measured at $730 \mathrm{~nm}$ (Spectrophotometer UV-3300, Mapada Instruments). Aqueous solutions of Trolox (concentrations between 0 and $200 \mathrm{M}$ ) were used for the calibration. The results were expressed as micromoles of trolox equivalents $(\mathrm{TE}) / \mathrm{l} 00 \mathrm{~g}$ of dry matter.

Total polyphenols 
The content of total polyphenolic compounds was determined using the Folin-Ciocalteu method (Contreras-Calderón et al., 2016). The absorbance was measured at 725 nm (UV-3300 Spectrophotometer, Mapada Instruments). Aqueous solutions of gallic acid (concentrations between 0 and I,000 mg/L) were used for the calibration. The results were expressed as milligram of gallic acid equivalents (GAE)/ $00 \mathrm{~g}$ of dry matter.

\subsection{Sensorial analysis}

The sensorial evaluation was carried out in the Sensorial Food Analysis Laboratory of the University of Antioquia. Participants were trained judges, aged between 25 and 55 years. The test used was a sensory profile by multidimensional approach according to NTC 3932 of 1996, where descriptors of appearance, smell, taste, and texture were evaluated taking into account a rating scale of $0-5$ ( 0 was absent and 5 was very intense). For the general quality descriptor, an acceptance scale of I-3 was established, where I was the lowest quality and 3 was the highest. The sensory analysis was made to the commercial sample, and to the coated potato with lower content of acrylamide and fat, according to the experimental design.

\subsection{Statistical analysis}

To analyze the effect of the application of the edible coating on the reduction of acrylamide and fat levels in potato chips, a multilevel factorial experiment design was applied. Three independent variables were evaluated: percentage of concentrated whey protein $(5,8$, and $11 \%)$, percentage of rosemary extract $(0$ and $2 \%$ ), and frying temperature $\left(171^{\circ} \mathrm{C}\right.$ and $\left.190^{\circ} \mathrm{C}\right)$. Moisture, firmness, fat, and acrylamide content were analyzed as response variables. The data were analyzed by means of an ANOVA table with a level of significance of $95 \%$. In addition, the main interactions of the factors on the analyzed responses were tested. All statistical analyses and graphic illustrations were studied using the statistical software STATGRAPHICS Centurion XVI. The experimental design is shown in Table 1 .

\section{RESULTS AND DISCUSSION}

\section{I. Physicochemical characterization of coated potato chips}

Table I shows the results for the firmness, moisture, fat, and acrylamide values obtained for the different treatments. Figure IA-D shows the main effects for each of the dependent variables studied in terms of the independent variables analyzed. Figure 2 represents the force-distance test to obtain the firmness values of the potato chips.

\section{I.I Moisture}

The moisture values for potato chips ranged from 4.6 to $33.4 \%$ (Table I). This range agrees with results found by Mousa (2018) in French fries coated with gum arabic and antioxidant extracts and by Aminlari, Ramezani, and Khalili (2005) in fried potatoes coated with concentrated whey protein and egg white. Different conditions did not significantly affect the moisture content of the potato $(p>0.05)$. However, as shown in Figure IA, the higher frying temperature, protein level in the coating, and rosemary content involve the lower moisture content in potato chips. This finding is due to the fact that when the temperature increases, the evaporation rate of water increases, leading to lower moisture content (Alvis, Gonzalez, \& Arrázola, 200I). In the case of the protein, on the one hand, higher processing temperatures induce denaturation by unfolding to form a network that traps water. Nevertheless, on the other hand, plasticization by water reduces protein-protein interactions, promotes mobility of the polymer chain, increases free volume, and as a result, increases the water diffusion, resulting then in reduced moisture in the final product (Kurek et al., 2017). Regarding the rosemary extract added to the coating, the higher lipid content partially changes the protein configuration, increasing its hydrophobic character on the surface 
(Djagny, Wang, \& Xu, 200I). Guerrero, Nur Hanani, Kerry, and de la Caba (20II) reported that the films with higher hydrophobicity showed an increase in the speed of water diffusion. This interaction can favor the lower moisture content in the coated potato chips when the amount of rosemary extract added in the coating is increased (Figure IA). Finally, moisture content for commercial and street vending chips was 5$6 \%$, respectively.

\subsubsection{Fat}

The fat content of potato chips subjected to the different treatments ranged between 8.0 and $31.5 \%$. In general, this content was not significantly affected $(p>0.05)$ by the factors studied (frying temperature, protein, \% rosemary). However, 8 of the 12 coated potatoes presented a fat content below that found in commercial chips (17.5\%), and all of them were lower than the fat content observed in the street vending chips (32.0\%). As depicted in Figure IB, the fat content decreased at higher frying temperature, higher rosemary content, and lower protein level. Moyano and Pedreschi (2006) reported that the higher the frying temperature, the lower the fat content in potato chips, which is in accordance with the results found in this investigation. In that sense, Suaterna (2009) found that the fat absorption in plant structures decreases at frying temperatures between 180 and $200 \mathrm{C}$, a range close to the frying temperatures of the present study. This phenomenon occurs because the crust prevents the movement of the steam bubbles toward the medium, preventing the moisture of the food to be replaced by oil. In addition, the formation of the crust attributes properties to the food similar to those of an insulation material (Alvis et al., 200I). Therefore, fat content in the potatoes (Figure IB). As described by Moreira, Sun, and Chen (1997), this finding can be probably explained due to the union between the polymer and the surface of the food was not adequate and perforations in the surface of the coating were formed favoring then the oil absorption because of high capillary forces. In contrast, it is possible that the coating based on whey protein was not sufficiently adhered to the potato. This behavior is described in Figure IB. In contrast, Aminlari et al. (2005) found that potato chips with whey protein coating exhibited less oil. In summary, oil absorption is influenced by different factors such as the time and temperature of frying, the quality of the oil, the previous treatments, and the composition (both the coating and the food) (Kurek et al., 2017), and many of which were controlled in the present study.

\subsubsection{Firmness}

Table $I$ and Figure 2 show the different values for the firmness of the coated potato chips. In general, treatments I, 4, 5, 9, and II, reached values of threshold of creep (rupture of bark) between 0.5 and $2 \mathrm{~N}$ indicating a state of low rigidity and high weakness. The other treatments had a yield threshold between 3 and $4 \mathrm{~N}$, being considered as rigid and fragile potato chips (Bourne, 2002). The firmness values obtained for street vending and commercial chips were on average 3 and $3.5 \mathrm{~N}$ (Table I), respectively. These values were similar to those of treatments 3,6,7, 8, and 10. All the treatments presented micro fractures (Figure 2), which are a sign of crispy products (Bourne, 2002). The results obtained in the present study are in agreement with those reported by Granda, Moreira, and Tichy (2004), who analyzed this parameter in potatoes of the Atlantic variety, under traditional frying conditions, obtaining values of compression force between 3 and $4 \mathrm{~N}$. In a similar way, Morales, Jimenez, Garcia, Remedios, and Ignacio (2014), reported firmness values between 3 and $5 \mathrm{~N}$ for French fries with added natural extracts.

Regarding the analysis of variance (ANOVA), none of the factors significantly affected the firmness ( $p>$ 0.05). However, a positive effect of the whey protein on the firmness of the potatoes was observed (Figure IC). In this sense, higher whey protein content in the coating lead to greater values of the firmness in the chips, in agreement with the results obtained for treatments $2,3,6,7,8$, and 10 . It could be explained due 
to the whey protein has the capacity to form gel when subjected to heating temperatures. It increases the retention of water and the elasticity of the final product (Yamul, 2008) and makes the food harder and less crispy. Some authors affirm that the concentration of proteins is directly related to the firmness of the gels and, therefore, of the final product (Juárez et al., 20II). This agrees with the moisture values presented in Table I and with those reported by Lucas, Dumar, Vasco, and Cuellar (20II), who found values between 2 and $43 \%$, for different treatments.

Similarly, the evaluation of the effect of rosemary extract content on the firmness of potato chips (Figure IC) shows that the greater the presence of extract is, the lower the firmness. This happens because the interaction protein-extract induces a weakening of the protein-protein structure, causing less rigidity and therefore less firmness in the potato chips (Choulitoudi, Ganiari, Tsironi, \& Ntzimani, 2017). In addition, increasing the frying temperature gives a greater firmness (Figure IC), that can be attributed to dehydration occurring in shorter time. This fact causes a structural contraction, improving the interaction between plant walls and intensifying the firmness of the final product (Kalogianni \& Papastergiadis, 20I4).

Equation (I) shows the technological model obtained for the firmness of the potatoes with coating subjected to frying. The equation presents an R2 of $75 \%$, which can be used to predict the firmness according to the frying conditions.

$$
\begin{array}{r}
F=5: 7783-3: 829 \mid P-2: 023 I R+0: 0287 T+0: 0217 P R \\
+0: 0075 P T+0: 0087 R T+0: 1639 P^{2}
\end{array}
$$

$(F)$ : Firmness of potato chips; $(P)$ : percentage of concentrated whey protein; $(R)$ : percentage of rosemary extract; $(T)$ : frying temperature.

\subsubsection{Acrylamide}

Table I shows the acrylamide values obtained for each treatment, which ranged between 86 and $650 \mu \mathrm{gg} / \mathrm{kg}$ of sample. Values were below $750 \mu \mathrm{g} / \mathrm{kg}$, which is the benchmark level indicated for potato chips by the EU Regulation 2158/2017 (European Commission, 2017). Acrylamide content in analyzed samples was similar to data reported by Pedreschi, Mariotti, Granby, and Risum (201 I), who reduced the acrylamide content of potato chips (from 2047 to $158 \mu \mathrm{g} / \mathrm{kg}$ ), applying some pretreatments including scalding and immersion in asparaginase solution. Jung, Choi, and Ju (2003) also demonstrated the reduction of acrylamide by $73 \%$, using a pretreatment with citric acid solution. In contrast, acrylamide values in the present study were lower than those described by Urbancic et al. (2014), who found values in potatoes fried in sunflower oil that oscillate between 184 and I,295 $(\mu \mathrm{g} / \mathrm{kg})$. In the present study, potatoes were immersed in an ascorbic acid solution at low concentration $(0.05 \%)$ to avoid significant effects on the antioxidant capacity of the samples and as a consequence on acrylamide formation (Capuano, Oliveiro, Açar, Gökmen, \& Fogliano, 2010).

The statistical analysis (ANOVA) showed that the acrylamide content was significantly affected by the frying temperature $(p<0.05)$ (Figure ID). The heating conditions favor the dehydration of the product, and therefore, the substrates (carbonyl group-free amino acid) converge more easily. Gökmen, Palazoglu, and Senyuva (2006) suggest that temperatures above 150 C significantly promote the formation of acrylamide, although other authors establish the level at temperature around $175^{\circ} \mathrm{C}$ (Yasuhara, Tanaka, Hengel, \& Shibamoto, 2003). 
Figure ID depicts that acrylamide content tends to decreases when the coating contains a higher percentage of rosemary extract; however, the changes were not significant $(p>0.05)$. This result is in agreement with the results reported by Urban ci c et al. (2014), who found that the formation of acrylamide is reduced by about $38 \%$, when rosemary extract was used frying sunflower oil. In that sense, the literature reports that natural antioxidants can interact with acrylamide precursors in two of the most important reactions that lead to their formation: the Maillard reaction and the oxidation of lipids (Ciesarová, Suhaj, \& Horváthová, 2008). In the case of the Maillard reaction, a fragment of the reducing sugar present in the potato reacts with the conjugate system of polyphenols with antioxidant capacity of rosemary extract, thus preventing the sugar from binding with asparagine to form acrylamide (Schieberle, Kohler, \& Granvogl, 2005). These results are in concordance with those reported by Jin, $\mathrm{Wu}$, and Zhang (2013), who demonstrated that the acrylamide content was reduced in fried potato slices when rosemary herb was added to the olive oil. Similarly, Hedegaard, Granby, Frandsen, Thygesen, and Skibsted (2008) added aqueous extract, and these authors added aqueous extract of rosemary, rosemary oil, and dried rosemary leaves to a bread model, thus reducing the acrylamide content by 62,67 , and $57 \%$, respectively, compared to bread without rosemary. In addition, Cheng, Chen, Zhao, and Zhang (2015) significantly reduced the formation of acrylamide by adding flavonoids in potatoes. However, several studies have described that the reduction in acrylamide formation is related to the presence of phenolic groups (Cheng et al., 2015; Zhu, Cai, Ke, \& Corke, 2009), because they can precipitate amino acids (Jin et al., 2013). Equation (2) shows the technological model obtained for the content of acrylamide in coated potato chips, with an R2 of $87 \%$, which can be used to predict the acrylamide content according to the frying conditions.

$$
\begin{aligned}
A=-2620,760-4|; 69|(P)+722 ; 782(R)+18 ; 57 \mid(T) \\
+12 ; 004\left(P^{2}\right)-15,056(P R)-0: 612(P T)-3 ; 728(R T)
\end{aligned}
$$

\subsection{Determination of antioxidant capacity and total phenolic compounds}

Taking into account the results obtained, the best treatment was number 7 , as it promoted the lowest content of acrylamide and fat and potato chips exhibited firmness close to that of the commercial chips. For that reason, the effect of frying on antioxidant capacity and total polyphenols was only measured in this sample (Table 2).

The concentration of antioxidants in potato chips increased 1.8 times as compared with the raw potato, which may be due to the addition of the rosemary extract and Maillard reaction during processing (Contreras-Calderón et al., 2016). As demonstrated in previous studies (Capuano et al., 2010), the application of ascorbic acid solution at low concentration $(0.05 \%)$ does not affect to the final antioxidant capacity of the treated samples. Values found in the present study were greater than those reported by Nem s and Pęksa (2018) who observed values from 68 to $90 \mu \mathrm{mol}$ TE/l00 g of dry matter in different varieties of potatoes grown in the Czech Republic. However, a higher content of antioxidants has been found in sweet potato varieties grown in Colombia (I I l-458 $\mu \mathrm{mol}$ TE/ $100 \mathrm{~g}$ of fresh weight) (Molina Cita et al., 2015), in purple potatoes that were processed by jet drying, with temperatures ranging from 50 to $80 \mathrm{C}(4200-4,500 \mu \mathrm{mol}$ TE/I00 g of dry matter) (Qiu, Wang, Song, Deng, \& Zhao, 20I8) and in processed potatoes as crisp (I,000-6,500 $\mu \mathrm{mol}$ TE/l00 g of dry matter) (Serpen \& Gökmen, 2009).

However, values for total phenolic content of fresh potato decreased 2.I times after frying (Table 2). These values are in the range reported in potatoes grown in Chile (from I9l to $1864 \mathrm{mg} \mathrm{GAE} / \mathrm{l} 00 \mathrm{~g}$ ) (Ah-Hen et al., 2012). These differences may be due to the type, conditions and agricultural practices of each crop, degree of maturation, and so on. In general, the antioxidant capacity can be increased by the addition of 
extract and the Maillard reaction, although part of the natural polyphenols can be lost during the thermal treatment (Contreras-Calderón et al., 2016), and this occurred in this study after frying the coated potato chips. However, it is also reported that polyphenols react with reducing sugars to form other compounds that are not measured in the polyphenols determination (Ciesarová et al., 2008), suggesting that the concentration of phenolic compounds can decrease or increase (Taylor \& Duodu, 20I5).

\subsection{Sensorial analysis}

The sensory evaluation was performed only to treatment 7 and to the commercial sample (Figure 3). The appearance parameter (Figure 3A), presented lower values respect to the commercial sample. It may be due to a low uniformity in color and irregularity in the form was observed. This result was also reported by Mousa (2018), who assured that the coated potatoes had a different appearance because of the higher moisture. However, this fact does not indicate a lack of acceptance by the consumer. The appearance of the potato is a frequent problem at industrial level, because it depends on the chemical composition of the tuber (reducing sugars). This composition, in turn, depends on many environmental and storage factors, because the reducing sugars determine the quality of the fried potato, providing a darker color and a bitter taste due to the participation in nonenzymatic browning reactions (Dilmer, 2007).

In the descriptors of odor (Figure 3B), the coated potato presented higher qualification in the oily, sweet, and toasted odor attributes, which is well perceived by the consumer (Mousa, 2018). In contrast, the commercial sample presented greater intensity in the rancid descriptor. Regarding flavor attributes (Figure 3C), the coated potato showed greater intensity in the flavor of potato starch, oily, toasted, and vegetable but without a rancid smell or flavor, which was described in the commercial potato which can be explained because it has been found that palm oil does not affect the organoleptic properties of fried foods (Pangloli, Melton, Collins, Penfield, \& Saxton, 2002). However, in the texture attributes (Figure 3D), the coated sample had a higher score in the attributes of hard, rubbery, and chewy texture, FIGURE 3 whereas the commercial sample obtained a higher score in the attributes fracturable, crispy, and adhesive. It is mainly due to the coagulation of the proteins, the gelling of the starch, and the partial dehydration suffered by the product (Singh, Blaisdell, Herum, Stevens, \& Cahill, 1985).

\section{CONCLUSIONS}

An edible coating based on protein and rosemary antioxidant extract for potato chips was developed. In addition, the acrylamide content obtained in this research complies with the EU Regulation 2158/2017. On average, the protein content increased the firmness of the fried potato, having values similar to those from a commercial potato chip. The coating model allowed developing a potato chip with lower content of acrylamide and fat, preserving the sensory and textural properties of this type of products, and with a higher content of antioxidants. Despite more studies are required, the use of edible coatings with antioxidants may be a viable alternative for the reduction of acrylamide and fat content in potato chips, which contributes to the improvement of public health.

\section{FUNDING}

Comunidad Autonoma de Madrid, Grant/Award Number: project P2018/BAA-4393-AVANSECAL-II-CM; Facultad de Ciencias Farmaceuticas y Alimentarias, Universidad de Antioquia, Grant/Award Number: Research Project CIQF 279

\section{ACKNOWLEDGEMENTS}


The authors gratefully acknowledge the Faculty of Pharmaceutical and Food Sciences, the financial support of research project CIQF-279, and the BIOALI and Sensory Food Analysis research groups of the Faculty of Pharmaceutical and Food Sciences, Antioquia University. This work was funded by project P2018/BAA-4393AVANSECAL-II-CM. Special thanks to Professor Diana Maria Granda for administrative support in the execution of the project.

\section{REFERENCES}

Ah-Hen, K., Fuenzalida, C., Hess, S., Contreras, A., Vega-Gálvez, A., \& Lemus-Mondaca, R. (20/2). Antioxidant capacity and total phenolic compounds of twelve selected potato landrace clones grown in southernchile. Chilean Journal of Agricultural Research, 72, 3,9.

Al-Asmar, A., Naviglio, D., Giosafatto, L., \& Mariniello L. (20/8). Hydrocolloid-based coatings are effective at reducing acrylamide and oil content of French fries.Coatings, I47: I, I3.

Albert, S., \& Mittal, G. S. (2002). Comparative evaluation of edible coatings to reduce fat uptake in a deepfried cereal product. Food Research International, 35(5), 445-458. https://doi.org//0.1016/S09639969(01)00139-9

Alvis, A., Gonzalez, A., \& Arrázola, G. (200I). Efecto del Recubrimiento Comestible en las Propiedades de Trozos de Batata (Ipomoea batatas Lam) Fritos por Inmersión. Parte 2: Propiedades Termofísicas y de Transporte (Vol. 26, pp. 103-II6). Revista médica de Chile. Córdoba: Scielo. https://doi.org//0.4067/S07/8$221 \times 2015005000053$

Aminlari, M., Ramezani, R., \& Khalili, M. H. (2005). Production of protein coated low-fat potato chips. Food Science and Technology International, II(3), I77-I8I. https://doi.org/I0.II77//0820 I3205054785

Andarwulan, N., Kurniasih, D., Apriady, R. A., Rahmat, H., Roto, A. V., \& Bolling, B. W. (2012). Polyphenols, carotenoids, and ascorbic acid in underutilized medicinal vegetables. Journal of Functional Foods, 4, 339-347. https://doi.org//0.1016/j.jff.2012.01.003

AOAC. (2005). Official methods of analysis (18th ed.). Gaithersburg, MD, USA: Association of Official Analytical Chemists.

Bejarano, J., \& Suarez, L. (20I5). Algunos peligros químicos y nutricionales del consumo de los alimentos de venta en espacios públicos. Revista de La Universidad Industrial de Santander. Salud, 47(3), 349-360. Retrieved from http://www.scielo.org.co/scielo.php?script=sci_arttext\&pid=SOI2I080720150003000 I I \&lng=en\&nrm=iso\&tlng=es

Bourne, M. C. (2002). Texture, viscosity, and food. In Food texture and viscosity: Concept and measurement (2nd ed.). New York: Academic Press.

Capuano, E., Oliveiro, T., Açar, O., Gökmen, V., \& Fogliano, V. (2010). Lipid oxidation promotes acrylamide formation in fat-rich model systems. Food Research International, 43, I02I-1026.

Cheng, J., Chen, X., Zhao, S., \& Zhang, Y. (20I5). Antioxidant-capacity based models for the prediction of acrylamide reduction by flavonoids. Food Chemistry, 168, 90-99. https://doi.org/10.1016/j.foodchem.2014.07.008 
Choulitoudi, E., Ganiari, S., Tsironi, T., \& Ntzimani, A. (2017). Edible coating enriched with rosemary extracts to enhance oxidative and microbial stability of smoked eel fi llets. Food Packaging and Shelf Life, 12 (December 2016), 107-113.

Ciesarová, Z., Suhaj, M., \& Horváthová, J. (2008). Correlation between acrylamide contents and antioxidant capacities of spice exracts in a model potato matrix. Journal of Food and Nutrition Research, 47, I-5.

Contreras-Calderón, J., Guerra-Hernández, E., \& García-Villanova, B. (2009). Utility of some indicators related to the Maillard browning reaction during processing of infant formulas. Food Chemistry, II4(4), 1265-1270. https://doi.org/10.1016/j.foodchem.2008.1 I.004

Contreras-Calderón, J., Mejía-Díaz, D., Martínez-Castaño, M., Bedoya-Ramírez, D., López-Rojas, N., GómezNarváez, F., \& Vega-Castro, O. (2016). Evaluation of antioxidant capacity in coffees marketed in Colombia: Relationship with the extent of non-enzymatic browning. Food Chemistry, 209, 162-170. https://doi.org//0.1016/j.foodchem.2016.04.038

De Grandi Castro Freitas, D., Berbari, S. A. G., Prati, P., Fakhouri, F. M., Collares Queiroz, F. P., \& Vicente, E. (2009). Reducing fat uptake in cassava product during deep-fat frying. Journal of Food Engineering, 94 (3), 390-394. https://doi.org/10.1016/j.jfoodeng.2009.04.005

Dilmer, J. (2007). http://www.redepapa.org/ calidadpapa.pdf

Djagny, K. B., Wang, Z., \& Xu, S. (200I). Conformational changes and some functional characteristics of gelatin esterified with fatty acid. Journal of Agricultural and Food Chemistry, 49(6), 2987-2991. https://doi.org//0.102I/jf00I3I5I

Dueik, V., \& Bouchon, P. (2016). Development of polyphenol-enriched vacuum and atmospheric fried matrices: Evaluation of quality parameters and in vitro bioavailability of polyphenols. Food Research International, 88, 166-172. https://doi.org/I0.1016/J.FOODRES.2016.03.032

EFSA. (2015). Scientific opinion on acrylamide in food. EFSA Journal, I3, 4104.

Embuscado, M. E. (2015). Spices and herbs: Natural sources of antioxidants - A mini review. Journal of Functional Foods, 18, 81I-819. https://doi.org/10.1016/j.jff.2015.03.005

European Commission (EU). (2017). Commission regulation 2017/2I58 of 20 November 2017 establishing mitigation measures and benchmark levels for the reduction of thepresence of acrylamide in food. Official Journal of the European Union, L304, 24-44.

Falguera, V., Quintero, J., Jiménez, A., Muñoz, J., \& Ibarz, A. (20II). Edible films and coatings: Structures, active functions and trends in their use. Trends in Food Science \& Technology, 22, 292-303.

Fernández Valdés, D., Bautista Baños, S., Fernández Valdés, D., Ocampo Ramírez, A., García Pereira, A., \& Falcón Rodríguez, A. (2015). Películas y recubrimientos comestibles: una alternativa favorable en la conservación poscosecha de frutas y hortalizas. Revista Ciencias Técnicas Agropecuarias, 24(3), $52-57$ Retrieved from http://scielo.sld.cu/scielo. php?script=sci_arttext\&pid=S207I $00542015000300008 \&$ lng=es\&nrm=iso\&tlng=es

Gökmen, V., Palazoglu, T. K., \& Senyuva, H. Z. (2006). Relation between the acrylamide formation and timetemperature history of surface and core regions of French fries. Journal of Food Engineering, 77, 972-976.

S. Trujillo-Agudelo et al. / J Food Process Eng. 2019; el3198 pag. I I 
Gomez, B., Martinez, J., \& Cardona, L. (20I4). Composición de ácidos grasos en algunos alimentos fritos y aceites de fritura y factores relacionados, en un sector universitario de Medellín-Colombia. Perspectivas en Nutrición Humana, 16, 159-174 Retrieved http://www.scielo.org.co/scielo.php?script=sci_arttext\&pid=S0 I 24-4 I 082014000200004

González, J., Bermúdez, A., \& Morales, J. (2017). Alternatives to reduce fat uptake during deep fat frying of food. International Journal of Advanced Research, 5(9), I-I4. https://doi.org//0.21474/IJAR0I/550I

Granda, C., Moreira, R. G., \& Tichy, S. E. (2004). Reduction of acrylamide formation in potato chips by lowtemperature vacuum frying. Journal of Food Science, 69, 405-4II.

Guerrero, P., Nur Hanani, Z. A., Kerry, J. P., \& de la Caba, K. (20II). Characterization of soy protein-based films prepared with acids and oils by compression. Journal of Food Engineering, 107(I), 4I-49. https://doi.org/l0.1016/j.jfoodeng.2011.06.003

Hedegaard, R. V., Granby, K., Frandsen, H., Thygesen, J., \& Skibsted, L. H. (2008). Acrylamide in bread. Effect of prooxidants and antioxidants. European Food Research and Technology, 227, 519-525.

IARC. (1994). Monographs on the evaluation of carcinogenic risks to humans: Some industrial chemicals, 60 , 389-433. Lyon, France: International Agency for Research on Cancer.

Jin, C., Wu, X., \& Zhang, Y. (2013). Relationship between antioxidants and acrylamide formation : A review. Food Research International, 5 I (2), 6I I-620. https://doi.org/I 0.10 I6/j.foodres.20 I 2.12.047

Juárez, M., Osawa, C., Acuña, M., Sammán, N., Guaraldo, L., \& Gonçalves, G. (20II). Degradation in soybean oil, sunflower oil and partially hydrogenated fats after food frying, monitored by conventional and unconventional methods. Food Control, 22, 1920-1927. https://doi.org//0.1016/j.foodcont.201 I.05.004

Jung, M. Y., Choi, D. S., \& Ju, J. W. (2003). A novel technique for limitation of acrylamide formation in fried and baked corn chips and in French fries. Journal of Food Science, 68, I287-1290.

Kalita, D., Holm, D. G., \& Jayanty, S. S. (2013). Role of polyphenols in acrylamide formation in the fried products of potato tubers with colored flesh. Food Research International, 54(I), 753-759. https://doi.org// 0.1016/J.FOODRES.2013.08.023

Kalogianni, E., \& Papastergiadis, E. (2014). Crust pore characteristics and their development during frying of. Journal of Food Engineering, 120, 175-182. https://doi.org// 0.1016/j.jfoodeng.2013.07.029

Kim, D. N., Lim, J., Bae, I. Y., Lee, H. G., \& Lee, S. (20I I). Effect of hydrocolloid coatings on the heat transfer and oil uptake during frying of potato strips. Journal of Food Engineering, 102(4), 317-320. https://doi.org//0.1016/j.jfoodeng.2010.09.005

Kurek, M., Šcetar, M., \& Gali c, K. (2017). Edible coatings minimize fat uptake in deep fat fried products: A review. Food Hydrocolloids, 7I, 225-235. https://doi.org/I 0.1016/j.foodhyd.2017.05.006

Liu, Y., Wang, P., Chen, F., Yuan, Y., Zhu, Y., Yan, H., \& Hu, X. (2015). Role of plant polyphenols in acrylamide formation and elimination. Food Chemistry, 186, 46-53. https://doi.org//0.1016/J.FOODCHEM.2015.03.122 
Lucas, J., Dumar, V., Vasco, J., \& Cuellar, L. (20II). Evaluación de los parámetros de calidad durante la fritura de rebanadas de papa criolla. Scientia et Technica, 48, 299-304.

Mallikarjunan, P., Chinnan, M. S., Balasubramaniam, V. M., \& Phillips, R. D. (1997). Edible coatings for deep-fat frying of starchy products. LWT -Food Science and Technology, 30(7), 709-7/4. https://doi.org//0.1006/fstl.1997.0263

Mesías, M., \& Morales, F. J. (2015). Acrylamide in commercial potato crisps from Spanish market: Trends from 2004 to 2014 and assessment of the dietary exposure. Food and Chemical Toxicology, 8I, 104I I0.https://doi.org/10.1016/j.fct.2015.03.03 |

Ministerio de la Protección Social. (20II). Encuesta Nacional de la Situación Nutricional en Colombia 2010. Ensin, 13-15.

Molina Cita, Y., Rabe Caez_Ramirez, G., Luisa, M., Quijano, R., Del, M., Lasso, S. C., \& Holguín, G. (20I5). ontenido de antioxidantes en papas criollas nativas (Solanum tuberosum L. grupo Phureja) en proceso deprecocción y congelación. Revista Alimentos Hoy, 23, 3I-4I.

Morales, G., Jimenez, M., Garcia, O., Remedios, M., \& Ignacio, C. (2014). Effect of natural extracts on the formation of acrylamide in fried potatoes. Food Science and Technology, 58(2), 587-593. https://doi.org/I0.1016/j.Iwt.2014.03.034

Moreira, R. G., Sun, X., \& Chen, Y. (1997). Factors affecting oil uptake in tortilla chips in deep-fat frying. Journal of Food Engineering, 3 I (4), 485-498. https://doi.org/I0.10I6/S0260-8774(96)00088-X

Mousa, R. (20/8). Simultaneous inhibition of acrylamide and oil uptake in deep fat fried potato strips using gum Arabic-based coating incorporated with antioxidants extracted from spices. Food Hydrocolloids, 83, 265-274. https://doi.org/10.1016/j.foodhyd.2018.05.007

Moyano, P. C., \& Pedreschi, F. (2006). Kinetics of oil uptake during frying of potato slices: Effect of pretreatments. LWT - Food Science and Technology, 39(3), 285-29I. https://doi.org//0.1016/j.Iwt.2005.01.010

Nems, A., \& Pęksa, A. (2018). Polyphenols of coloured-flesh potatoes as native antioxidants in stored fried snacks. LWT—Food Science and Technology, 97, 597-602. https://doi.org//0.1016/j.lwt.2018.07.053

Nieto, C. (2014). Técnicas de cocción: sabor, color, textura y nutrientes a buen recaudo. Farmacia Profesional, 28(4), 15-19.

OMS. (2018). Alimentación sana. OMS. Retrieved from http://www.who.int/es/news-room/factsheets/detail/healthy-diet

Pangloli, P., Melton, S. L., Collins, J. L. Penfield, M.P. y Saxton, A.M. (2002).“Flavor and storage stability of potato chips fried in cottonseed and sunflower oils blends". Journal of Food Science 67, 97-103.

Pedreschi, F., Mariotti, S., Granby, K., \& Risum, J. (20II). Acrylamide reduction in potato chips by using commercial asparaginase in combination with conventional blanching. Food Science and Technology, 44 (6), |473-|476. https://doi.org/10.1016/j.Iwt.201 I.02.004 
Qiu, G., Wang, D., Song, X., Deng, Y., \& Zhao, Y. (20/8). Degradation kinetics and antioxidant capacity of anthocyanins in air-impingement jet dried purple potato slices. Food Research International, 105, 121-128. https://doi.org/10.1016/j.foodres.2017.10.050

Rimac-Brn ci c, S., Lelas, V., Rade, D., \& Šimundi c, B. (2004). Decreasing of oil absorption in potato strips during deep fat frying. Journal of Food Engineering, 64(2), 237-24l. https://doi.org//0.1016/j.jfoodeng.2003.10.006

Schieberle, P., Kohler, P., \& Granvogl, M. (2005). New aspects on the formation and analysis of acrylamide. In M. Friedman \& D. Mottram (Eds.), Chemistry and safety of acrylamide in food (Vol. 56I) (pp. 205-222). New York: Springer.

Serpen, A., \& Gökmen, V. (2009). Evaluation of the Maillard reaction in potato crisps by acrylamide, antioxidant capacity and color. Journal of Food Composition and Analysis, 22, 589-595. https://doi.org/10.1016/j.jfca.2008.11.003

Silva, K. D. R. R., \& Sirasa, M. S. F. (2018). Antioxidant properties of selected fruit cultivars grown in Sri Lanka. Food Chemistry, 238, 203-208. https://doi.org/10.1016/j.foodchem.2016.08.102

Singh, Y., Blaisdell, J., Herum, F., Stevens, K., \& Cahill, V. (1985). Texture profile parameters of cooked frankfurter emulsions as influenced by cooking treatment. Journal of Texture Studies, 16, 169-177. https://doi.org// 0.1 III/j.1745-4603.1985.tb00689.x

Sothornvit, R. (20II). Edible coating and post-frying centrifuge step effect on quality of vacuum-fried banana chips. Journal of Food Engineering, 107(3), 319-325. https://doi.org//0.1016/j.jfoodeng.2011.07.010

Suaterna, A. (2009). Deep frying: Nutrient losses and profits from fried foods. Perspectivas en Nutrición Humana, 10, 77-88.

Suyatma, N., Ulfah, K., Prangdimurti, E., \& Ishikawa, Y. (20I4). Effect of blanching and pectin coating as prefrying treatments to reduce acrylamide formation in banana chips. International Food Research Journal, 22(3), I.

Taylor, J. R., \& Duodu, K. G. (2015). Effects of processing sorghum and millets on their phenolic phytochemicals and the implications of this to the health-enhancing properties of sorghum and millet food and beverage products. Journal of the Science of Food and Agriculture, 95(2), 225-237. https://doi.org//0.1002/jsfa.67/3

Urbancic, S., Kolar, M. H., Dimitrijevic, D., Demšar, L., \& Vidrih, R. (20l4). Stabilisation of sunflower oil and reduction of acrylamide formation of potato with rosemary extract during deep-fat frying. LWT - Food Science and Technology, 57, 67I-678. https://doi.org/10.1016/j.Iwt.2013.11.002

Xu, C., Yagiz, Y., Marshall, S., Li, Z., Simonne, A., Lu, J., \& Marshall, M. R. (2015). Application of muscadine grape (Vitis rotundifolia Michx.) pomace extract to reduce carcinogenic acrylamide. Food Chemistry, I82, 200-208. https://doi.org//0.1016/J.FOODCHEM.2015.02.133

Yamul, D. (2008). Propiedades de geles de concentrado de proteínas de lactosuero, miel y harina. Tesis de Doctorado. Centro de Investigación y Desarrollo en Criotecnología de Alimentos. Universidad Nacional de la Plata, Argentina. 
Yang, Y., Achaerandio, I., \& Pujolà, M. (2016). Influence of the frying process and potato cultivar on acrylamide formation in french fries. Food Control, 62, 216-223. https://doi.org//0.1016/j.foodcont.2015.10.028

Yasuhara, A., Tanaka, Y., Hengel, M., \& Shibamoto, T. (2003). Gas chromatographic investigation of acrylamide formation in browning model systems. Journal of Agricultural and Food Chemistry, 5 I (14), 39994003.

Yu, L., Li, J., Ding, S., Hang, F., \& Fan, L. (2016). Effect of guar gum with glycerol coating on the properties and oil absorption of fried potato chips. Food Hydrocolloids, 54, 21I-219. https://doi.org/10.1016/j.foodhyd.2015.10.003

Zeng, X., Cheng, K.-W., Du, Y., Kong, R., Lo, C., Chu, I. K., Wang, M. (2010). Activities of hydrocolloids as inhibitors of acrylamide formation in model systems and fried potato strips. Food Chemistry, 12I(2), 424428. https://doi.org/10.1016/j.foodchem.2009.12.059

Zhu, F., Cai, Y., Ke, J., \& Corke, H. (2009). Evaluation of the effect of plant extracts and phenolic compounds on reduction of acrylamide in an asparagine/glucose model system by RP-HPLC-DAD. Journal of the Science of Food and Agriculture, 89(10), 1674-168I. https://doi.org/I0.1002/jsfa.3640 


\section{FIGURES AND TABLES}

Table I. Multilevel factorial experimental design and physical and physicochemical characterization of French fries with a coating based on whey protein and rosemary extract, commercial potatoes and street vending.

\begin{tabular}{llllllll}
\hline \multirow{2}{*}{ Samples } & $\begin{array}{l}\text { Frying } \\
\text { temperature }\end{array}$ & Protein & $\begin{array}{l}\text { Rosemary } \\
\text { extract }\end{array}$ & Firmness & Moisture & Fat & Acrylamide \\
& ${ }^{\circ} \mathbf{C}$ & $\%$ & $\%$ & $\mathbf{N}$ & $\%$ & $\%$ & $\mathbf{\mu g} / \mathbf{k g}$ \\
\hline $\mathbf{I}$ & 171 & 11 & 2 & $1.134 \pm 0.189$ & $6.7 \pm 0.5$ & $8.0 \pm 0.1$ & $186 \pm 8$ \\
$\mathbf{2}$ & 190 & 11 & 2 & $5.721 \pm 1.763$ & $9.3 \pm 0.6$ & $25.5 \pm 0.3$ & $292 \pm 2$ \\
$\mathbf{3}$ & 171 & 11 & 0 & $3.103 \pm 0.573$ & $4.6 \pm 0.7$ & $31.5 \pm 0.9$ & $451 \pm 8$ \\
$\mathbf{4}$ & 190 & 8 & 2 & $0.888 \pm 0.444$ & $11.4 \pm 0.8$ & $15.5 \pm 0.2$ & $296 \pm 18$ \\
$\mathbf{5}$ & 171 & 5 & 2 & $1.704 \pm 0.874$ & $8.3 \pm 0.7$ & $17.5 \pm 0.8$ & $131 \pm 13$ \\
$\mathbf{6}$ & 190 & 11 & 0 & $3.704 \pm 0.947$ & $5.9 \pm 0.4$ & $9.5 \pm 0.4$ & $650 \pm 16$ \\
$\mathbf{7}$ & 190 & 5 & 2 & $2.810 \pm 0.767$ & $19.7 \pm 0.5$ & $9.8 \pm 0.3$ & $229 \pm 7$ \\
$\mathbf{8}$ & 190 & 5 & 0 & $3.678 \pm 1.097$ & $5.3 \pm 0.5$ & $15.8 \pm 0.7$ & $485 \pm 8$ \\
$\mathbf{9}$ & 171 & 5 & 0 & $1.311 \pm 0.080$ & $33.4 \pm 0.3$ & $15.5 \pm 0.1$ & $138 \pm 4$ \\
$\mathbf{1 0}$ & 190 & 8 & 0 & $3.190 \pm 0.953$ & $11.5 \pm 0.1$ & $10.0 \pm 0.8$ & $320 \pm 27$ \\
$\mathbf{I 1}$ & 171 & 8 & 2 & $0.516 \pm 0.075$ & $5.0 \pm 0.3$ & $11.5 \pm 0.5$ & $146 \pm 10$ \\
$\mathbf{1 2}$ & 171 & 8 & 0 & $1.087 \pm 0.834$ & $16.7 \pm 0.5$ & $21.0 \pm 0.9$ & $86 \pm 0.2$ \\
Comercial & - & - & - & $3.50 \pm 0.38$ & $6.0 \pm 0.2$ & $17.5 \pm 0.1$ & $549 \pm 72$ \\
Street vending & - & - & - & $3.00 \pm 0.67$ & $5.5 \pm 0.9$ & $32.0 \pm 0.9$ & $233 \pm 11$ \\
\hline
\end{tabular}


Table 2. Antioxidant capacity (ABTS) and total phenolic content for the treatment 7 before and after frying

\begin{tabular}{ccc}
\hline Analysis & Sample & Concentration/100 g dry matter \\
\hline $\begin{array}{c}\text { ABTS } \\
(\mu \mathrm{mol} \text { TE) }\end{array}$ & Fresh potato & $688 \pm 45$ \\
& Coated French fries & $1271 \pm 102$ \\
\hline Total phenolic content (mg AGE) & Fresh potato & $518 \pm 38$ \\
& Coated French fries & $246 \pm 5$ \\
\hline
\end{tabular}

TE: Trolox equivalent. GAE: Gallic acid equivalent. 
Figure I. Effects of frying temperature, whey protein and rosemary extract on (A) moisture, (B) fat, (C) firmness and (D) acrylamide in French fries.
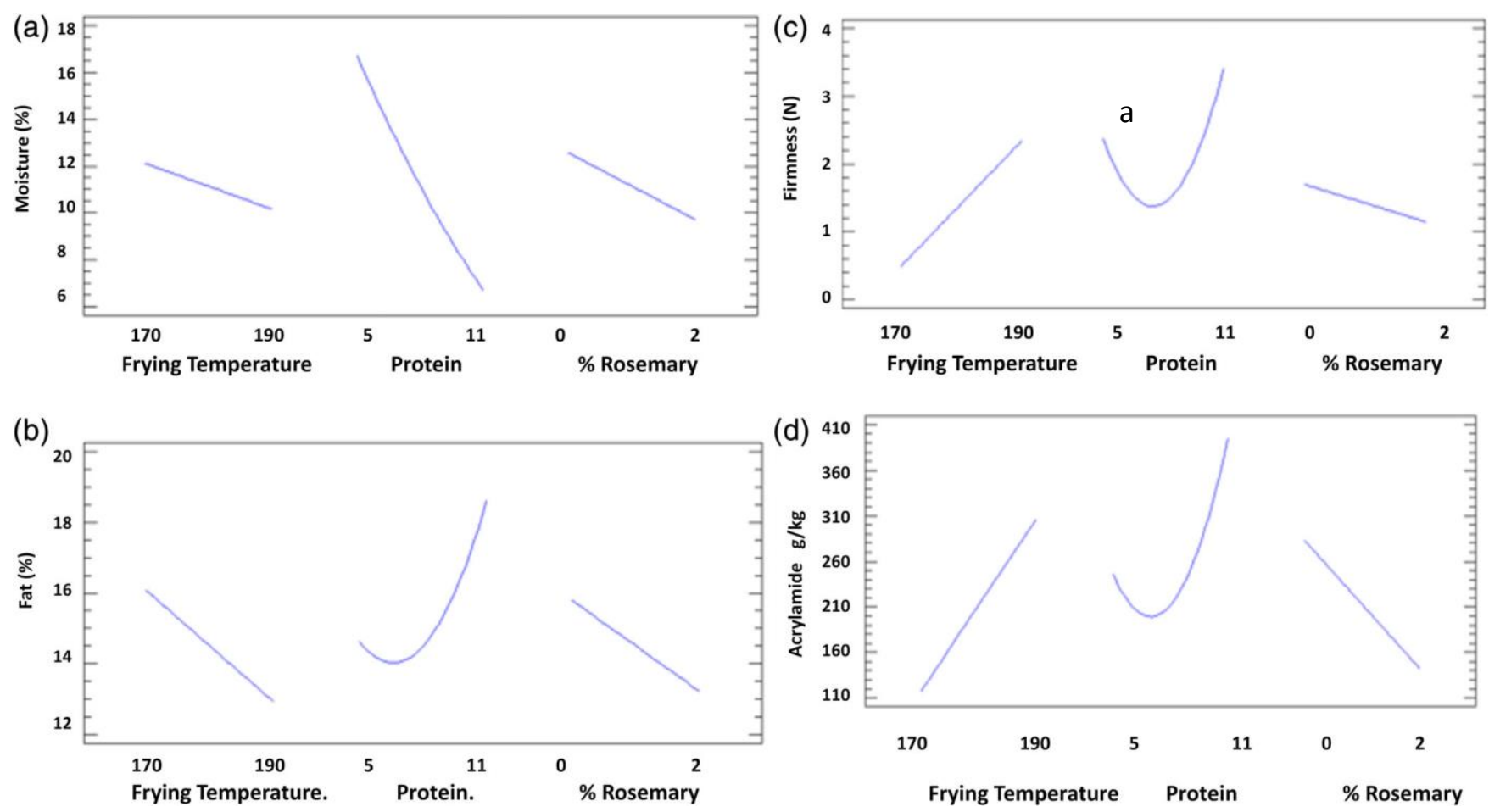
Figure 2. Force-distance test for the different treatments analyzed.

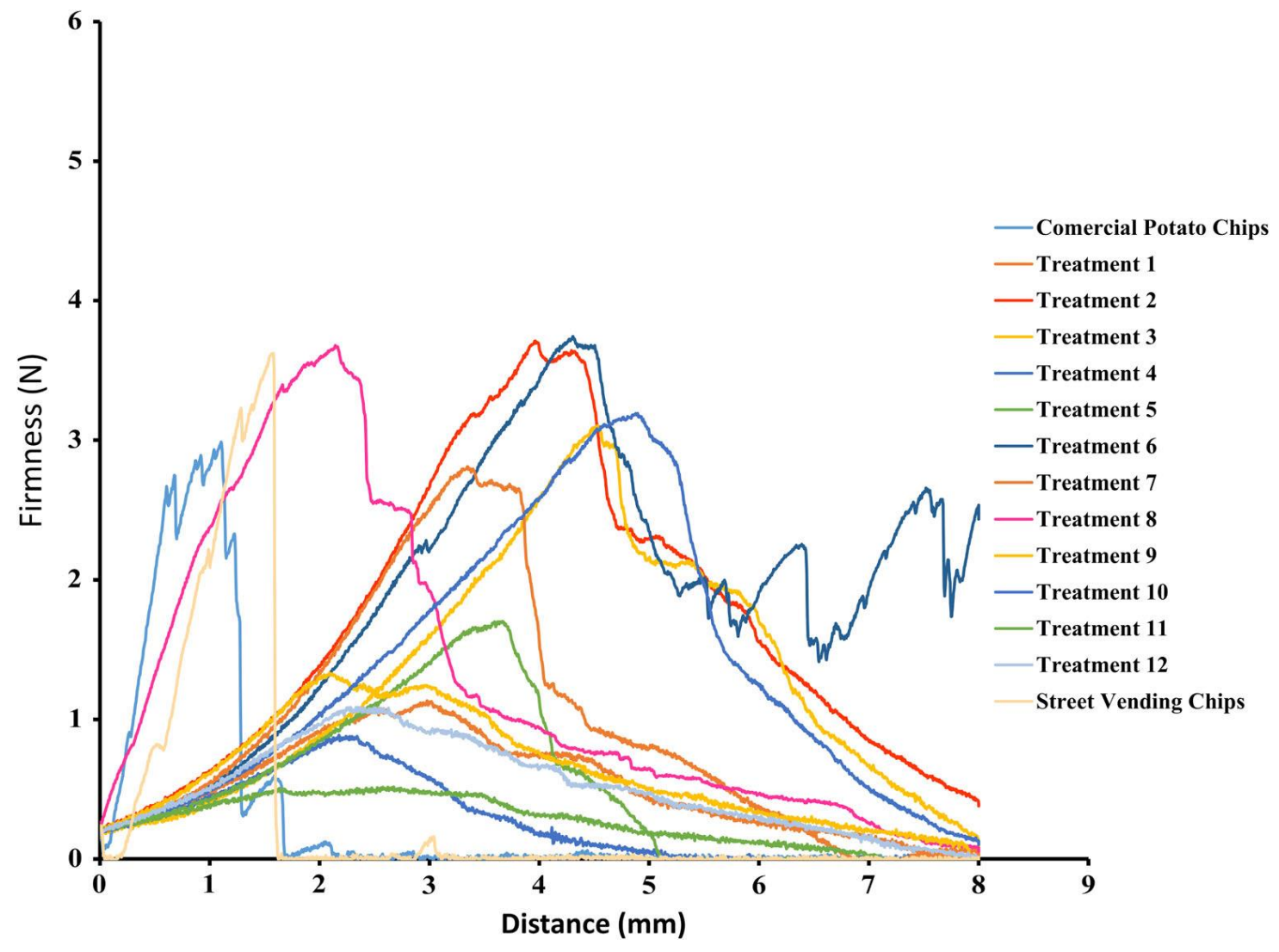


Figure 3. Sensory profile by multidimensional approach for treatment 7 and commercial sample: (A): Appearance attributes, (B): Odor attributes, (C): Taste attributes, (D): Texture attributes.
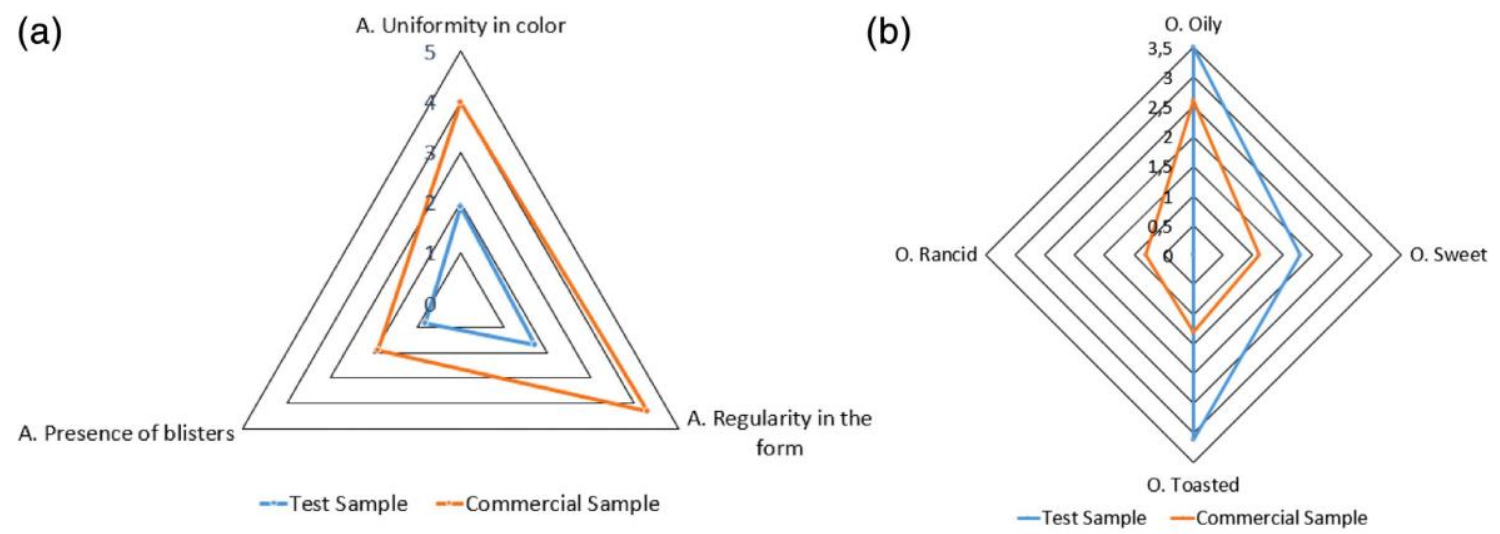

(c)
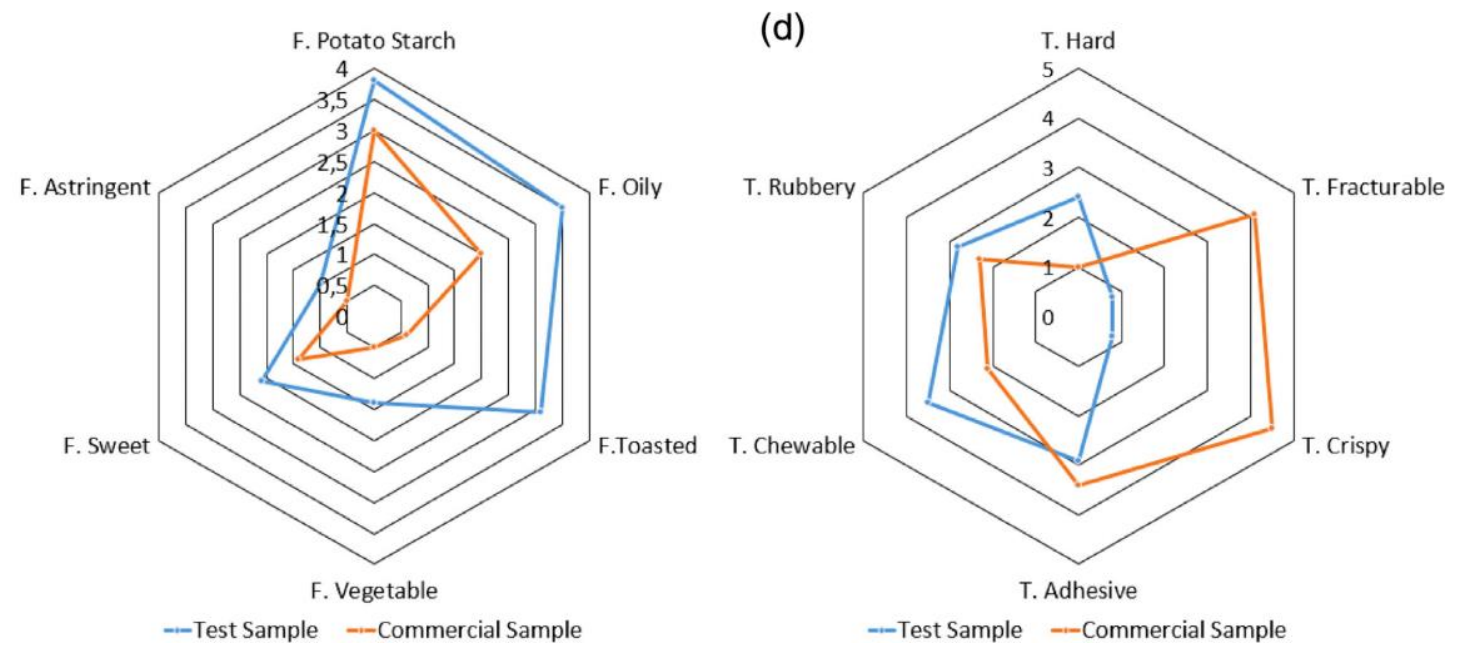